The 49th Annual Conference of the International Association of School Librarianship

The 24th International Forum on Research on School Librarianship

July $12-16,2021$

Virgilio Medina Jr; Ross J. Todd

Qatar National Library; State University of New Jersey

vmedina@qnl.qa; rtodd@rutgers.edu

\title{
Implementing STEM-related Activities for School Aged Users
}

\begin{abstract}
Published literature acknowledges the importance of Science, Technology, Engineering, and Mathematics (STEM) education in various educational institutions and its contributions to the future of a nation's economy. This paper focuses on successful library STEM-based programs that were undertaken from August to September 2019 for school-aged users in a public library. This paper also explores users' perceptions in attending STEM-based activities in the library as well as their feedback on how future library programs on STEM could further be improved. These findings seek to provide new perspectives for librarians, educators, teachers, and staff in creating opportunities for STEM-based initiatives in an informal learning environment.
\end{abstract}

Keywords: Public libraries, STEM, young adults, school libraries

\section{Introduction and Statement of Research Problem}

Published literature acknowledges the importance of STEM in various educational institutions and its contributions to the future of a nation's economy. Informal learning environments such as libraries and museums can play a vital role to develop students' skills and knowledge for STEM and even ignite student interests about STEM (Denson et al., 2015). Despite the continuous emphasis on the importance of STEM needs, many public libraries are still struggling to design their own program due to the lack of training support, resources, and right approaches that are geared for students' needs (Baek, 2012). With this, this paper explores the innovative roles of a public library in facilitating STEM-based programs for school aged users and how users perceive library STEM-based programs as part of their learning experience.

\section{Literature Review}

\section{Public Libraries and STEM}

Several international organizations and professional associations in library and information science highlight the significant roles of public libraries in fostering STEM by creating a space that provides access to authentic learning experiences (Australia Library and Information Science, 2017; Young Adult Library Services Association, 2013). Roberson (2015) claims that STEM-based library activities are becoming popular among library users. It is believed that libraries are part of a "STEM learning ecology" that provides invaluable resources, particularly 
for children and families, to cultivate their learning and development (Lopez, Jacobson, Caspe, \& Hanebutt, 2019, p. 9). Duncan and Murnane (2014) identify libraries' roles in fostering STEM within the community through various events such as makerspaces, exhibitions, and childrenand family-oriented activities that provide opportunities for attendees to learn STEM concepts (as cited in Lopez, Jacobson, Caspe, \& Hanebutt, 2019, p. 5). Similarly, Dusenberry (2013) argues that having STEM programs in libraries creates more opportunities to engage users, particularly in science and technology. Lopez et al. (2019) explain that public libraries link formal and informal environments while providing opportunities for children and young adults to collaborate with their families. They also state that libraries have the capacity to support students' STEM needs which could also lead to meeting the future job demands. Through partnerships and collaborations with other schools and education organizations, libraries are enabled to fill the gap in the learning needs (Fitzgibbons, 2000).

\section{Partnership Between Schools and Public Libraries}

Evidence supports the need for establishing successful collaborations between schools and public libraries. Shannon (1991) believes that partnerships between school and public libraries maximizes resource use and allows students to effectively meet their learning needs. Potter and Johnson (2017) describe public libraries and school libraries as "natural partners" that share common users (p. 24). They note that both types of libraries undertake meaningful collaborations in order to address patron needs not only for resources, but also to support curriculum and activities, particularly to assist student achievement. Likewise, Dotson, Yontz, and Jones (2018) indicate that this kind of collaboration creates opportunities for students to cultivate deep knowledge, attain effective learning experiences, and promote lifelong learning. They affirm that this is a "win-win" situation in which both parties gain various benefits such as "improved access to resources unavailable in school libraries; increased equity in terms of student access to varied materials; improved academic success; increased student engagement and literacy; increased knowledge of resources to support life-long learning; and learning is extended beyond the classroom with access to more resources" (p. 5).

\section{Methodology}

As mentioned above, this paper explores the innovative roles of a public library in facilitating STEM-based programs as well as users' perceptions in participating in STEM-based library activities. Fifty four library users from grades 3 to 10 completed a paper-based survey as part of the monthly library programming, which took place from August to September 2019. Library activities included: Building blocks, STEM for young adults, LEGO making (see Figure 1). This data collection was performed at the end of each program. Survey questions centered on demographic profile, previous library program experience, frequent participation, source of information about library activities, perceptions about STEM concepts (Roberts et al, 2018), and feedback about improving future library programs. Users who have difficulty understanding 
some survey questions received assistance from their parents or an Arabic or English speaker library staff.

\section{Figure 1}

Sample STEM activities that were held at Qatar National Library



In terms of grade level(see Figure 2), a majority of them are Grade $8(26 \%, n=14)$, followed by Grade $7(22 \%, n=12)$, and Grade $6(17 \%, n=9)$. There were some attendees in Grade $3(9 \%, \mathrm{n}$ $=5)$, Grade $4(7 \%, n=4)$, Grade $5(7 \%, n=4)$, Grade $9(6 \%, n=3)$ and Grade $10(6 \%, n=3)$.

\section{Figure 2}

Demographic Profile

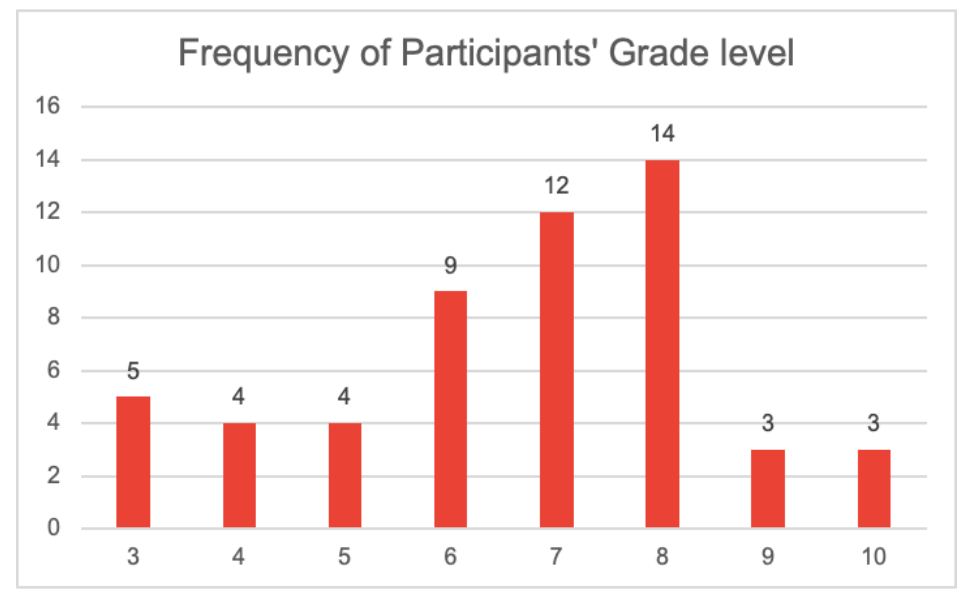




\section{Results}

\section{Source of Information}

Participants were asked how they knew about the program,and a majority of the attendees $(80 \%$, $n=43)$ mentioned the library website. Six (11\%) of them said others, and five (9\%) selected word of mouth. Others specifically identified their source of information as a parent's influence, invited by friends, and library visits. This gathered data explains that the library website seems to be the most effective marketing tool to promote STEM-related activities in the library and to attract school-aged users to attend these sessions. What this data tells us is that a library website could be an effective tool to further strengthen the library's marketing strategy in promoting STEM-based programs. This also provides a clear picture that the library website could be a starting point to introduce new programs on STEM and encourage the community to participate in future library programs.

\section{Users' Registration Satisfaction}

The library provides different ways for participants to register in library programming either through an online registration or walk-in during the library event. Online registration requires users to provide information such as personal details and email address, while walk-in participants need to fill out the attendance sheet in the actual library session, which is a first-come first served basis, in order to ensure a slot. In terms of the registration process (see Figure 3), most of the participants $(59 \%, n=32)$ indicated "very satisfied", and $15(28 \%)$ respondents expressed "satisfied" with their overall registration experience. Six (11\%) attendees said "neutral," while only one participant (2\%) said they were very dissatisfied. It is evident here that participants' registration experience is also a factor when it comes to facilitating library activities because this determines the accessibility and convenience for users to participate in library events.

\section{Figure 3}

\section{Users'Registration Satisfaction}






\section{Users' Reasons for Attending the Program}

The study explored the reasons why participants attended the program in the library. The survey question provided a list of choices. As Figure 4 shows, most respondents $(61 \%, n=33)$ answered that they are "interested in the topic or to learn new or improve skill". Ten of them (19\%) said they are influenced by their parents to attend the program. Nine (17\%) participants disclosed that they want to try a library program. However, two of them (4\%) did not provide any answer to this question. One of the interesting findings here is that participants are eager to learn something new and develop new skills by attending a library program, and this also notes that they perceive the library as an opportunity to learn some skills outside their classroom. Lastly, this may be a good notion that they view their public library as a place to acquire knowledge and experience hands-on learning through library programs on STEM.

\section{Figure 4}

Users'Reasons for Attending the Program

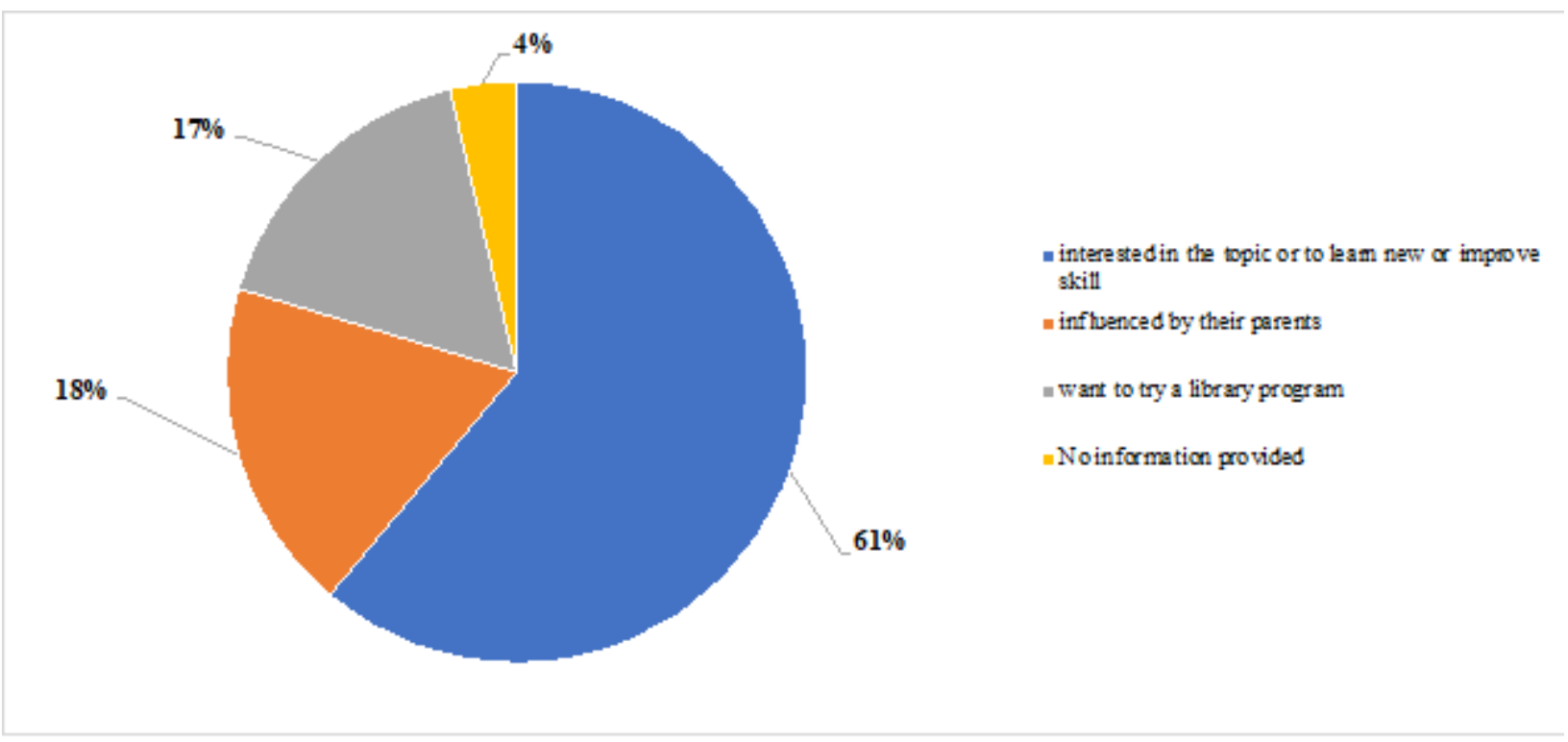

\section{Users'Perceptions about STEM}

Another question explored users' perceptions of STEM concepts. It could be noted that 15 (28\%) participants incorporated the concept of STEM to Science, Technology, Engineering, and Mathematics. Eight (15\%) viewed it as "Science", five (9\%) respondents thought it as "Technology," and two (4\%) said "Math." Four (7\%) believed that STEM is related to their academics or education. Only one (2\%) mentioned that STEM is related to the library activity they did. Seven $(13 \%)$ of them admitted that they have no idea about this. Surprisingly, twelve (22\%) respondents stated unique descriptions about STEM such as "Fun," "my future," "plants," "books," "medicine," and "the world." What we can conclude here is that the library needs to 
make efforts to further promote the importance of STEM among school-aged users. The library should be consistent in building partnerships with schools to support and complement students' classroom experience by promoting STEM-based library programs outside their schools or as extra-curricular activities.

\section{Users' Recommendations for Future Library Programs}

Figure 5 shows the list of users' feedback terms generated through an online word generator software. What we could see here is a majority of the respondents suggested that the library should offer more STEM-based library programs by having more tools, activities, and more spaces. Many of them also mentioned that they have nothing to say regarding the program they attended. Some participants recommended specific activities that can be done in the library such as Art and Craft, 3D printing, Engineering-related activities, LEGO making, Robotics, video editing, and photoshop. These findings reveal different insights: that the library has more reasons to offer more STEM-based library offerings in the future; that the library should be consistent in providing STEM programs that are localized and designed for school aged users; that participants appreciate the library's efforts in creating spaces for STEM-based initiatives. Overall, the library seems to be a perfect place for school-aged users to develop their skills on STEM and to prepare them for their future STEM career aspirations. Some of the comments include:

Attendee 1: "You can start coding classes or video editing or adobe photoshop"

Attendee 2: "More sessions on STEM that can help me in my future career"

Attendee 3: "More STEM like this"

\section{Figure 5}

Users' recommendations for future library programs






\section{Conclusion}

The findings presented here reveal that school-aged users see the public library as an avenue to experience authentic learning experiences such as STEM-based programs, not only as a traditional place for storage of printed and digital resources. This paper also hopes to bring new perspectives to library professionals, educators, and stakeholders in the aspect of facilitating and promoting STEM-based programs in the community that enable users to develop various skills necessary for their future workplace. By understanding the users and their needs in terms of STEM programs, this will create opportunities for libraries to revamp and revisit their programs as to how they can effectively identify the STEM needs within their community. Questions like: to what extent does the library maximize its resources in supporting STEM needs? and what professional support can be extended to ensure all library professionals are equipped in providing STEM programs? could inform future studies. With the rising needs for STEM across the globe, the role of libraries will take an important place as an informal learning environment to further engage their community in various STEM library programs.

\section{References}

Australian Library and Information Association. (2017). How public libraries contribute to the STEM agenda 2017 [Text]. Retrieved October 24, 2019, from: https://read.alia.org.au/how-public-libraries-contribute-stem-agenda-2017

Baek, J. Y. (2013). Public libraries as places for STEM learning: An exploratory interview study with eight librarians. Space Science Institute, 1-17.

Denson, C., Austin, C., Hailey, C., \& Householder, D. (2015). Benefits of informal learning environments: A focused examination of STEM-based program environments. Journal of STEM Education, 16(1).

Dotson, K. B., Yontz, E., \& Jones Jr, P. A. (2018). Public libraries and school libraries: Partnerships to support truth in history. North Carolina Libraries, 76(1). https://doi.org/10.3776/ncl.v76i1.5345

Duncan, G. J., \& Murnane, R. J. (2014). Restoring opportunity: The crisis of inequality and the challenge for American education. Harvard Education Press.

Dusenbery, P. (2013, September 13). The STEM Education Movement in Public Libraries. InformalScience.org. Retrieved from https://www.informalscience.org/stem-education-movement-public-libraries

Fitzgibbons, S. A. (2000). School and public library relationships: Essential ingredients in implementing educational reforms and improving student learning. School Library Media Research, 3 .

https://www.ala.org/aasl/sites/ala.org.aasl/files/content/aaslpubsandjournals/slr/vol3/SLM R_SchoolPublicLibRelationships_V3.pdf 
Lopez, M. E., Jacobson, L., Caspe, M., \& Hanebutt, R. (2019). Public libraries engage families in STEM. Global Family Research Project.

Potter, T., \& Johnson, K. (2017). Two libraries working toward common goals. Knowledge Quest, 45(5), 23-29.

Roberson, T. L. (2015). “STEM”-ulating young minds: Creating science-based programming@ your library. Journal of Library Administration, 55(3), 192-201.

https://doi.org/10.1080/01930826.2015.1034041

Shannon, D. M. (1991). Cooperation between school and public libraries: A study of one North Carolina county. North Carolina Libraries, 49, 67-70.

Young Adult Library Services Association. (2017, February 13). STEAM Toolkit [Text].

Retrieved October 24, 2019, from Young Adult Library Services Association (YALSA) website: http://www.ala.org/yalsa/steam-toolkit 